\title{
Education and Universalism in Europe: When Education Supports Democracy ${ }^{1}$
}

\author{
By Fiorenzo Parziale* \& Sandra Vatrella ${ }^{*}$
}

The increasing of unemployment, social insecurity and poverty are making many Europeans contest the democratic foundations of Europe. It is a world systemic crisis that, on the one hand, nurtures the migration flows, on the other hand, it intensifies the individualist tenets of neoliberalism and contemporarily the hostility against migrants to which the social insecurity is often attributed because in a sense they are the evident proof of the end of welfare assured by Nation-State in the past. In this context, it is relevant to understand the role of education in promoting the "democratic universalism", the founding value of democracy according to which institutions should remove social inequalities. Today this value is in crisis also because it asks to be re-elaborated recognising cultural pluralism, especially if we consider European societies are becoming multicultural increasingly.

Keywords: Democracy, Educational Mobility, Social Inequalities, Universalism

\section{Introduction: The Crisis of Democratic Universalism}

The article aims to understand the role formal education plays in promoting "democratic universalism". With this concept we mean the idea according to which the leading role of democratic institutions should be assuring both the removing of social barriers that hinder equality and contemporarily the recognition of the Other, considering the current pluralistic societies, especially in Europe (Honneth 2016, Geiselberger 2017).

It is a topic we deal with starting from some reflections on the crisis both of egalitarianism (Crouch, 2004) and "liberal secularism" (Žižek 2017), otherwise defined as "cultural liberalism" (Sciolla, 2013).

Regarding the crisis of egalitarianism, in the last decades neoliberalism fostered the process of capitalist expansion on a global scale, on the one hand by placing the immediate financial return before the medium-long-term productive investment (Piketty 2014), on the other hand by making the workers pay for the enterprise risk and the capitalist competition (Gallino 2013).

Therefore, we may attribute the crisis of egalitarianism to the individualism that neoliberalism has produced over time through both an economic system that encourages competition and the declaration that consumers' satisfaction is more

\footnotetext{
*Assistant Professor, Sapienza-University of Rome, Italy.

${ }^{\dagger}$ Postdoctoral Research Fellow, University of Verona, Italy.

${ }^{1}$ This work comes from a common effort; however, if you would attribute the single sections, paragraphs 1, 3, and 4.2 were written by Fiorenzo Parziale, and paragraphs 2 and 4.1 by Sandra Vatrella. Lastly, the paragraph 5 was written jointly by the two authors.
} 
relevant than the workers' rights (Harvey 2007, Crouch 2014).

Consequently, discontent because of unemployment and social insecurity connected to the financial crisis in 2007 has often given rise to the request of securitarian more than egalitarianism policies.

It is within this context that we may also identify the crisis of "cultural liberalism". In particular, we refer to the growing hostility of Europeans towards immigrants from Africa and the Middle East, and the related lack of recognition of these as people with the same rights and duties of natives: the combination of the impoverishment of workers and strong individualism hinders the recognition of strangers.

As Taylor (1994) notes, cultural liberalism promotes the multiculturalism rather than hindering it, insofar as it recognises and enhances individual autonomy against the constraints of religious or secular traditions.

For this reason, the process of delegitimisation of cultural liberalism risks translating universalism into a lack of recognition of socio-cultural differences (Ferrara 2011, Marramao 2015), thus undermining the possibility of ensuring social equality in today's multicultural societies (Cuche 2006) ${ }^{2}$.

Summing up, what we are dealing with is the fact that negative opinions and hostile attitudes towards minorities call into question the enactment of the democratic universalism in our current societies. Briefly, the lack of recognition of others affects the capability of recognising each as belonging to the same human community, so threatening the guiding principle of social equality.

Thanks to discovering the link between recognition of others and social equality, then we can understand how the crisis of universalism shows up not only among the subordinate classes, who are generally more suspicious towards migrants but also between the upper and middle classes ${ }^{3}$. About this, renowned scholars (e.g. Nussbaum 1997) state that nowadays school could be and represent the main agency able to spread the value of democratic universalism.

In consideration of this observation, and by resorting to the level of formal education as an indicator of scholastic socialisation, in what follows we analyse the degree in which the scholastic socialisation positively affects the individuals' attitude towards democratic universalism.

\section{Formal Education and Universalism: Theoretical Framework and Hypothesis}

Since the beginning of the twentieth century, scholars from different approaches studied the relationship between scholastic socialisation and

\footnotetext{
2 The negative attitudes towards minorities and immigrants are due, at least in part, to identity policies (holding at a global scale) useful to veil the failures of State in regulating economy (Appadurai 2017).

${ }^{3}$ In fact, advantaged classes declare themselves to be more inclined to cultural liberalism, and thus to multiculturalism, however they often give unfavourable opinions on the measures aiming to both remove socio-economic inequalities and promote the universal right to citizenship that allows individuals to take effectively part in public affairs.
} 
democracy: Dewey (1916) thought that formal education fed democratic culture; Lipset (1960) linked the possession of educational credentials to political participation. More generally, Elias (1936) saw in the school one of the main protagonists of the civilisation process.

Nowadays, though, the scholars who follow the Rational Choice theory challenge such an optimist approach, highlighting how the possession of a high level of education does not lead to greater mind-openness. According to them, education does not free individuals from the specific social position they occupy and from the interests associated with them (Wodtke 2012).

So, e.g. the influence that school education exerts on prejudice would disappear or at least it would be reduced significantly if it is assessed by putting under control the effects of the social position and/or income on the degree of appreciation for cultural diversity (Malchow-Møller et al. 2006). Conversely, some scholars advocate a sort of "scholastic cultivation" theory (Gerbner et al. 1986). They state that the possession of a high degree of formal education (conceived as an indicator of scholastic socialisation) positively affects the leanings and attitudes towards the democratic universalism. Consistently, some researches highlight how the levels of formal education are strictly linked to the openness to cultural diversity (Hainmueller and Hiscox 2007, Assirelli 2014); however, other researches (see Brint 1996) highlight the connection of education level and approval of cultural differences, but not the relationship between the former and egalitarianism on the economic side.

However, as we will show further, the data we analysed demonstrate the possibility to reset this issue in a theoretical framework focused on the complex nature of cultural processes.

Indeed, the scholastic socialisation is a communicative process in which the interpretative practice plays a key role, despite the influence that the social position exerts (Thompson 1995).

In summary, the approach we propose combines the critical hermeneutic with the social phenomenology aiming for a broader neo-Marxian theoretical framework, that makes use of the most critical contributions of the Sociology of Knowledge (Mannheim 1936, Izzo 1966), of the Sociology of Education (Willis 1977, Apple 2004, 2013) and the Sociology of Culture (Williams 1973, Hall 1980).

By resorting to this theoretical framework, we can conceive the scholastic socialisation as a cultural process based on both the social nature of individual thought (Marx and Engels 1845) and a dialectical relationship between praxis and symbolic production. On the one hand, the individual internalises norms, values, and beliefs from his social condition, on the other hand, the transmitted messages are also objectivations (Berger and Luckmann 1966) that in turn effect, as texts, by shaping the individual identity (Ricoeur 1986).

In our study, what we constantly bear in mind is that schools can promote the same universalistic ideology that often betrays (Parziale 2016). More specifically, the formal instruction has a double nature: it is an instrumental resource useful to acquire an advantageous social position, as underline the rational choice scholars (Boudon 1973, Goldthorpe 2000), but is also a social mobility resource that 
promotes the belief in universalism (Collins 1979, Brint 1998).

On the one hand, schools reproduce the social inequalities, denying its universalistic promise (Bukodi and Goldthorpe 2012, Jackson 2013); on the other hand, that promise nourishes expectations of social equality, because it produces universalistic identities. In this sense, particularly significant are the widespread emancipatory practices put into practice by various teachers and educators moved by a particularly critical political-cultural orientation (Giroux 2005, Apple 2013, Giroux and McLaren 2014, Mayo 2015) just because they have acquired the universal worldview point that schools in part transmit. In other words, we want to underline the cognitive and symbolic function of schools that consists of giving students not only values and norms but also beliefs connected with an emancipatory vision of the world. In this sense, we can identify the main inconsistency of modern schools: they distribute educational credentials that reproduce social inequalities, and at the same time they feed a worldview point that promotes equality and the recognition of the other.

If we were right, then a long scholastic socialisation may mitigate the selfishness connected to the advantageous social positions thanks to its fostering of universalism. This mechanism ought to be more effective towards people from subordinate social classes, opening them up to cultural diversity linked to foreign presence. Indeed, educational mobility requires students of modest social background to acquire an "elaborate cultural code" that they do not initially have (Bernstein 1975).

Therefore, what we are going to do is to corroborate the two following hypotheses on the relationship between formal education and democratic universalism:

1. Formal education has a positive impact on universalism, given the "symbolic-cognitive" function of school socialisation, even with the same social class and institutional context;

2. The orientation towards universalism should be positive and greater in those who have experienced upward educational mobility, capable of making them acquire a representation of the world favourable to the recognition of the other combined with the request of social justice deriving from the critical reflection of their social origins.

\section{Data, Method, Techniques}

Our empirical research is based on the elaboration of data gathered by the sixth wave of the European Social Survey (ESS), carried on in 2012. In particular, we chose to analyse 25-65 years old interviewees that reside in 23 of 30 Countries reached by this wave: we excluded residents in not European Countries (Russia and Israel) or in European Countries whose number of interviewees has resulted very small (Albany, Cyprus, Estonia, Kosovo, Iceland).

With the aim to corroborate our hypotheses, at the beginning we thought to elaborate a unique index useful to measure democratic universalism, conceived as 
the dependent variable; therefore we planned two regression models, one to investigate the first hypothesis, the other one to control the second hypothesis.

The separation in two models was due to the semantic overlap, then confirmed by statistic collinearity, between the independent variable concerned to education and the other variable used to measure educational mobility, that already considers educational level. Nonetheless, principal component analysis (Di Franco and Marradi 2003) has highlighted that our database makes we study universalism only employing two components not correlated each other $(r=0.064)$ : one component is about egalitarianism as principle founding democracy, the other one is connected to the approval of multiculturalism.

The egalitarianism index was elaborated through three variables built through Cantril scale (0-10), whereas the other index is made up of two variables measured with this scale and three ordinal variables that were also converted in numerical ones (Table 1).

Table 1. The Two Components of Democratic Universalism. Description of Indexes

\begin{tabular}{|c|c|c|c|}
\hline \multicolumn{2}{|l|}{ Egalitarianism* } & \multicolumn{2}{|c|}{ Multiculturalism** } \\
\hline Variable & \begin{tabular}{|c|}
$\begin{array}{c}\text { Factor } \\
\text { score } \\
\text { coefficient }\end{array}$ \\
\end{tabular} & Variable & $\begin{array}{c}\text { Factor } \\
\text { score } \\
\text { coefficient }\end{array}$ \\
\hline $\begin{array}{l}\text { It's important for democracy }(0 \text { : } \\
\text { not at all important-10: extremely } \\
\text { important): the government } \\
\text { protects all citizens against } \\
\text { poverty }\end{array}$ & 0.418 & $\begin{array}{l}\text { Allow immigrants of } \\
\text { different race/ethnic as } \\
\text { majority to come here: } 1 . \\
\text { None, 2. Few, 3. Some, } 4 . \\
\text { Many }\end{array}$ & 0.261 \\
\hline $\begin{array}{l}\text { It's important for democracy ( } 0 \text { : } \\
\text { not at all important-10: extremely } \\
\text { important): the government takes } \\
\text { measures to reduce differences in } \\
\text { income levels }\end{array}$ & 0.392 & $\begin{array}{l}\text { Allow immigrants from } \\
\text { poorer country outside } \\
\text { Europe to come here: } 1 . \\
\text { None, 2. Few, 3. Some, } 4 . \\
\text { Many }\end{array}$ & 0.251 \\
\hline $\begin{array}{l}\text { It's important for democracy ( } 0 \text { : } \\
\text { not at all important-10: extremely } \\
\text { important): the government } \\
\text { explains its decisions to voters }\end{array}$ & 0.386 & $\begin{array}{l}\text { Allow immigrants of } \\
\text { same race/ethnic as } \\
\text { majority to come here: } 1 . \\
\text { None, 2. Few, 3. Some, } 4 . \\
\text { Many }\end{array}$ & 0.241 \\
\hline & & $\begin{array}{l}\text { Immigrants make country } \\
\text { a better or worse place to } \\
\text { live: } 0 . \text { worse }-10 \text {. better }\end{array}$ & 0.226 \\
\hline & & $\begin{array}{l}\text { Country's cultural life is } \\
\text { undermined or enriched } \\
\text { by immigrants: } 0 . \\
\text { undermined-10. enriched }\end{array}$ & 0.224 \\
\hline
\end{tabular}

*Egalitarianism reproduces $69.8 \%$ of variance; **Multiculturalism reproduces $68.7 \%$ of variance

Therefore, first we had to proceed to double the two linear regression models, in order to consider the two indexes extracted in a separate way; then, we chose to resort to a final polynomial logistic regression model that could evaluate the 
interviewees' likelihood to be simultaneously favourable for equality and multiculturalism, namely of being "universalists" rather than "particularists".

In detail, we identified four types of interviewees: "only egalitarians" (favourable to equality, but unfavourable to multiculturalism: their score is more than 0 on the first index, but it is only equal to 0 or even negative on the second index), "only multiculturalists" (favourable to multiculturalism, but unfavourable to equality: their score is more than 0 on the second index, but it is only equal to 0 or even negative on the first index), "particularists" (their scores are equal to 0 or even negative on the two indexes; therefore they are unfavourable to both values), "universalists" (their scores are positive on the two indexes, so they are favourable to both values).

Consistently with the first hypothesis, we attributed to (formal) educational level the status of the main regressor. About this, we examined an ordinal variable subdivided in the following way: 1) without upper secondary education; 2) with upper secondary education (included advanced vocational); 3) with at least lower tertiary education.

With the aim to analyse the second hypothesis, instead, we replaced this variable with another one corresponding to a typology of educational mobility, achieved by the intersection between parents' educational level and individual educational level. We subdivided interviewees into five groups: 1) those with an "Upward (educational) Mobility", namely individuals with an educational level higher than their parents' one; 2) individuals with an "Immobility at the Top", namely interviewees with at least lower tertiary education like the parent with the highest level of education; 3) those with "Immobility in the Middle", who are individuals with Upper secondary education (advanced vocational included) and belonging to a family where the highest level of education is just this one; 4) interviewees with a "Downward Mobility", that are individuals with an educational level lower than their parents' one; 5) persons with "Immobility at the Bottom", namely individuals remained devoid of upper secondary tier just like their parents.

Among the other variables examined in all models, besides gender (male/female) and age cohort (25-35 years old; 36-50 years old; 51-65 years old), we analysed social class. We consider the occupational position as the most important proxy of social class condition (Goldthorpe 2000). In our classification we drew inspiration from the successful international schema proposed by Erikson, Goldthorpe and Portocarero (1979), also considering the following reworked versions (Goldthorpe 2000, 2016), and at the same time from the observations made by Marxist scholars, like Olin Wright (1985).

In summary, we preferred as a criterion for classification of interviewees the degree of control exercised on own work and possibly on the others' one.

We believe that this parameter gives us information both on the degree of commodification connected to production relationships between social classes (Wright), and on the individual relationship with the labour market (Goldthorpe).

From these considerations, we attributed to the Upper Class, those interviewees who are entrepreneurs (with at least ten employees) and managers, namely individuals characterised by a high degree of control not only on own 
work but also on the other people's one.

For statistical reasons we are constrained to aggregate this class to another one made up of an updated version of the Service Class, on which Alvin Gouldner (1979) focused in the past: this class consists of those who practice an intellectual work, but without necessarily occupy a power position like that employers and managers have; we mean intellectuals and professionals, who distinguish themselves for the high control on own work rather than for the control on organizations and above all on the other people's labour force (Parziale and Scotti 2008) .

Manual workers together with the lower qualified clerks, conceived as new workers in the tertiarised society (Oesch 2003), occupy an opposite position to the middle-upper class: the arrangements of their payment is rigidly regulated, while their work is subject to routine and strict supervision by entrepreneurs and managers. As the lower qualified clerks have a higher degree of freedom than manual workers, therefore we can distinguish two working classes: a traditional, made up of manual employees, and a new working class composed of non-manual workers.

Instead, we placed in the middle classes: a) small business owners, namely own-account workers without or with employees (with up to 9), that generally live an halfway situation between that one experienced by great entrepreneurs and working class; b) clerks and technicians with a middle-high qualified level, namely employees with less control over their work than professionals, but in an advantaged condition as compared to manual workers and lower qualified clerks: as Erikson and Goldthorpe (1992) spotted, the employment relations are in the halfway between real salaried labour and the professionals' service relation. Finally, our schema is completed by individuals who are resulted unemployed or inactive at the time the survey was conducted.

Data were weighted on the basis of a variable called "New_weights", that corresponds to the product of the other two variables supplied by ESS: "design weights" and "population size weights".

Our weighting neutralised mistakes deriving by the different distribution of interviewees on the basis their origin Country, and it makes us obtain good evaluations about the data related to different groups of Countries.

About this, we wanted to analyse also the role of a contextual variable that clusters the 23 Countries here considered on the basis of "welfare state regime": we took inspiration from Esping Andersen's classification (Esping-Andersen 2013). Therefore we subdivided countries in five groups: Centre-Western Countries (namely with "corporative welfare state regime": Belgium, France, Germany, Nederland, Switzerland), Anglo-Saxon Countries (with "neoliberal welfare state regime": UK and Ireland), Scandinavian Countries (with "universalist welfare state regime": Denmark, Finland, Norway, Sweden), Southern Countries (in this area of Europe we have a "familistic welfare state regime": Italy, Portugal, Spain), and Eastern Countries, in other words a group composed by the ex-soviet bloc countries belonging to Europe (Bulgaria, Czech Republic, Estonia, Hungary, Lithuania, Poland, Slovakia, Slovenia, Ukraine), with a specific welfare state regime, in spite of inner differences (Aidukaite 2011) . 
We also identified collinearity between the variable corresponding to this classification and the variable related to the geographic area. Therefore considering also this last feature is redundant: the first variable also includes the effect exercised by geographic area. Table 2 describes, in summary, our sample, composed by 20,866 valid cases.

Table 2. Description of Sample

\begin{tabular}{|c|c|c|}
\hline Variables & $\begin{array}{c}\text { Categories } \\
\end{array}$ & Values \\
\hline \multirow{3}{*}{ Educational level } & Without upper secondary education & 41.8 \\
\hline & With Upper secondary education* & 36.8 \\
\hline & At least lower tertiary education & 21.4 \\
\hline \multirow{4}{*}{ Type of interviewees } & Particularists & 18.1 \\
\hline & Only Egualitarians & 26.5 \\
\hline & Only Multiculturalists & 21,0 \\
\hline & Universalists & 34.5 \\
\hline \multirow{5}{*}{ Educational mobility } & Immobility in the Middle & 30.6 \\
\hline & Downward Mobility & 6.9 \\
\hline & Upward Mobility & 19,0 \\
\hline & Immobility at the Top & 6.2 \\
\hline & Immobility at the Bottom & 37.3 \\
\hline \multirow{2}{*}{ Gender } & Female & 52.8 \\
\hline & Male & 47.2 \\
\hline \multirow{3}{*}{ Age } & $25-35$ & 23.3 \\
\hline & $36-50$ & 39.3 \\
\hline & $51-65$ & 37.4 \\
\hline \multirow{6}{*}{ Social Class } & Middle-Upper Class & 16.1 \\
\hline & Middle Lower Class & 29.4 \\
\hline & Small Business Owners & 10.6 \\
\hline & Non-manual Working Class & 14.5 \\
\hline & Manual Working Class & 25.5 \\
\hline & Unemployed or Inactive & 3.9 \\
\hline \multirow{5}{*}{ Context (Welfare Regime) } & Centre-Western & 37.2 \\
\hline & Anglo-Saxon & 9,0 \\
\hline & Scandinavian & 5.3 \\
\hline & Southern & 25.8 \\
\hline & Eastern & 22.7 \\
\hline $\mathrm{N}$. & & 20,866 \\
\hline
\end{tabular}

*Advanced vocational included.

\section{Findings}

The Importance of Formal Educational Level, in Spite of Social Competition

As we wrote, principal component analysis led us to identify two different features of democratic universalism. On the one hand, there is the multiculturalism, namely the degree of openness to cultural diversity and especially to migrants; on the other hand, there is the egalitarianism that is the idea 
according to which democracy should be based on the promotion of social equality (see Table 1).

Our data show a deep difference towards the distribution of the two indexes (Table 3), that aren't correlated. Indeed, the index of multiculturalism has a distribution more symmetric: the minimum value $(-2.5)$ is not very different from the maximum one $(+1.9)$ in absolute terms. Instead, the egalitarianism index is characterized by a minority of cases with values very negative, whereas the maximum value $(+0.8)$ is not only lower to the half of the corresponding value got by the multiculturalism index, but it is also very different from the minimum value, that instead is high a lot (-5.8).

In summary, there is a significant minority of $14.5 \%$ of Europeans that show a great repulsion to the egalitarianism, whereas a relevant $60 \%$ of individuals take a position against them as they express a positive, also if moderate, propensity to this value.

In reverse, the bipartition between multiculturalists and individuals closed to the cultural diversity is more balanced, with the extreme poles that tend to be equivalent (Table 4) ${ }^{4}$.

Table 3. The Distribution of the Two Indexes

\begin{tabular}{|l|c|c|c|}
\hline Values & Quartiles & Multiculturalism & Egalitarianism \\
\hline Mean & & 0 & 0 \\
\hline Median & & 0.139 & 0.322 \\
\hline Mode & & 0.1 & 0.8 \\
\hline Standard Deviation & & 1 & 1 \\
\hline Skewness & & -0.304 & -1.680 \\
\hline Minimum & & -2.5 & -5.8 \\
\hline Maximum & & 1.9 & 0.8 \\
\hline Percentiles & 25 & -0.692 & -0.502 \\
\hline & 50 & 0.139 & 0.322 \\
\hline & 75 & 0.613 & 0.826 \\
\hline
\end{tabular}

Table 4. The Ordinal Distribution of the Two Indexes

\begin{tabular}{|l|c|c|}
\hline Classes & Multiculturalism & Egalitarianism \\
\hline From minimum to -1 & 16.7 & 14.5 \\
\hline From -0.99 to 0 & 31.0 & 25.1 \\
\hline From 0.1 to 1 & 37.0 & 60.4 \\
\hline From 1 to maximum & 15.3 & - \\
\hline
\end{tabular}

Multiculturalism splits public opinion more than Egalitarianism; indeed the second one is approved from the majority but in a moderate way, and it is strongly opposed by a minority, to which a fourth of 25-65 years old individuals with a slightly negative attitude towards to this value has to be added.

Therefore, there is not a minority such egalitarian that balances individuals with a very negative propensity to this value: in general way data seem to confirm

\footnotetext{
${ }^{4}$ Principal component analysis standardizes variables, therefore the indexes obtained have a mean equal to 0 and the standard deviation equal to 1 .
} 
how much Crouch (2014) states about the crisis of egalitarianism. If we stratify interviewees for social class and education, we find out the mean score of egalitarianism is higher among degree unemployed, followed by workers (manual and not manual one) with upper secondary education (advanced vocational included). Among middle classes (included small business owners) the repulsion towards this value increases how much education is higher, whereas among upperclass individuals graduates are the less unfavourable to equality (Table 5).

Table 5. Egalitarianism and Multiculturalism: Comparison of Means between Social Classes Stratified by Education Level (Means)

\begin{tabular}{|c|c|c|c|}
\hline Social Class & Highest Level of Education & Egalitarianism & Multiculturalism \\
\hline \multirow{4}{*}{$\begin{array}{l}\text { Middle-Upper } \\
\text { Class }\end{array}$} & At least lower tertiary education & -0.109 & 0.489 \\
\hline & $\begin{array}{l}\text { Upper secondary education (advanced } \\
\text { vocational included) }\end{array}$ & -0.254 & 0.008 \\
\hline & Without upper secondary education & -0.152 & -0.125 \\
\hline & Total & -0.105 & 0.448 \\
\hline \multirow{4}{*}{$\begin{array}{l}\text { Middle Lower } \\
\text { Class }\end{array}$} & At least lower tertiary education & -0.106 & 0.337 \\
\hline & $\begin{array}{l}\text { Upper secondary education (advanced } \\
\text { vocational included) }\end{array}$ & 0.023 & 0.119 \\
\hline & Without upper secondary education & 0.066 & -0.027 \\
\hline & Total & 0.015 & 0.108 \\
\hline \multirow{4}{*}{$\begin{array}{l}\text { Small Business } \\
\text { Owners }\end{array}$} & At least lower tertiary education & -0.238 & 0.480 \\
\hline & $\begin{array}{l}\text { Upper secondary education (advanced } \\
\text { vocational included) }\end{array}$ & -0.037 & -0.025 \\
\hline & Without upper secondary education & 0.034 & -0.287 \\
\hline & Total & -0.036 & -0.063 \\
\hline \multirow{4}{*}{$\begin{array}{l}\text { Non-manual } \\
\text { Working Class }\end{array}$} & At least lower tertiary education & 0.004 & 0.267 \\
\hline & $\begin{array}{l}\text { Upper secondary education (advanced } \\
\text { vocational included) }\end{array}$ & 0.107 & -0.038 \\
\hline & Without upper secondary education & 0.034 & -0.253 \\
\hline & Total & 0.057 & -0.128 \\
\hline \multirow{4}{*}{$\begin{array}{l}\text { Manual Working } \\
\text { Class }\end{array}$} & At least lower tertiary education & 0.050 & 0.188 \\
\hline & $\begin{array}{l}\text { Upper secondary education (advanced } \\
\text { vocational included) }\end{array}$ & 0.104 & -0.195 \\
\hline & Without upper secondary education & 0.061 & -0.329 \\
\hline & Total & 0.073 & -0.276 \\
\hline \multirow{4}{*}{$\begin{array}{l}\text { Unemployed or } \\
\text { Inactive }\end{array}$} & At least lower tertiary education & 0.245 & 0.378 \\
\hline & Upper secondary education* & 0.010 & 0.042 \\
\hline & Without upper secondary education & -0.043 & -0.453 \\
\hline & Total & 0.012 & -0.214 \\
\hline \multirow{4}{*}{ Total } & At least lower tertiary education & -0.095 & 0.429 \\
\hline & $\begin{array}{l}\text { Upper secondary education (advanced } \\
\text { vocational included) }\end{array}$ & 0.043 & 0.003 \\
\hline & Without upper secondary education & 0.049 & -0.251 \\
\hline & Total & 0.014 & -0.010 \\
\hline
\end{tabular}

*Advanced vocational included.

These findings have to be explained considering the interaction between education and social class. Indeed, education can be conceived as a "component variable" of social condition (Rosenberg 1968). For example, few individuals are devoid of tertiary education when they belong to the middle- 
upper class, whereas about $60 \%$ of workers or unemployed are even without high school diploma, and only a small minority of them has a degree.

In absolute terms education level seems to influence positively only on multiculturalism (see Table 5), whereas egalitarianism is preferred by individuals who are more disadvantaged in labour market but own not very low educational resources. Therefore the "relative education" rather than that "absolute one" (Nie et al. 1996) would seem to exercise a positive influence on egalitarianism. Indeed, the basically more disadvantaged individuals assume an attitude more favourable towards equality when they have a cultural capital higher than the other members of their same group: this is the case of workers with upper secondary education compared to those without this qualification, or of unemployed with tertiary education compared to those with a lower education level.

The importance of relative education level rather than that absolute one has to be reconnected to the unbalanced distribution of education level between social classes (Table 6).

Table 6. Social Class Stratified for Education Level

\begin{tabular}{|l|c|c|c|c|}
\hline & $\begin{array}{c}\text { Without upper } \\
\text { secondary } \\
\text { education }\end{array}$ & $\begin{array}{c}\text { Upper secondary } \\
\text { education } \\
\text { (advanced } \\
\text { vocational } \\
\text { included) }\end{array}$ & $\begin{array}{c}\text { At least lower } \\
\text { tertiary } \\
\text { education }\end{array}$ & Total \\
\hline $\begin{array}{l}\text { Middle-Upper } \\
\text { Class }\end{array}$ & 3.9 & 3.8 & 92.3 & $\begin{array}{c}100 \\
(3,359)\end{array}$ \\
\hline $\begin{array}{l}\text { Middle-Lower } \\
\text { Class }\end{array}$ & 30.2 & 51.3 & 18.5 & $\begin{array}{c}100 \\
(6,135)\end{array}$ \\
\hline $\begin{array}{l}\text { Small Business } \\
\text { Owners }\end{array}$ & 49.3 & 35.6 & 15.0 & $\begin{array}{c}100 \\
(2,212)\end{array}$ \\
\hline $\begin{array}{l}\text { Non-manual } \\
\text { Working Class }\end{array}$ & 42.3 & 44.2 & 13.6 & $\begin{array}{c}100 \\
(3,025)\end{array}$ \\
\hline $\begin{array}{l}\text { Manual } \\
\text { Working Class }\end{array}$ & 59.1 & 36.7 & 4.2 & $\begin{array}{c}100 \\
(5,320)\end{array}$ \\
\hline $\begin{array}{l}\text { Unemployed or } \\
\text { Inactive }\end{array}$ & 60.5 & 31.9 & 7.6 & $100(815)$ \\
\hline Total & 41.8 & 36.8 & 21.4 & $\begin{array}{c}100 \\
(20,866)\end{array}$ \\
\hline
\end{tabular}

This observation leads us to think that education level exercises a contradictory influence on egalitarianism because it promotes the recognition of the other, but it also represents a resource useful to achieve an advantaged social position, becoming a source of social distinction (see Bourdieu 1979).

Our multiple regression models confirm that multiculturalism depends on formal education level when social class and other variables we examined are held constant: what is important is the possession of degree (Table 7). 
Table 7. Multiple Linear Regression Model: The Effect of Formal Education Level on Multiculturalism, other Conditions being Equal

\begin{tabular}{|c|c|c|c|c|c|c|c|}
\hline & $\begin{array}{c}\text { Unstandardized } \\
\text { coefficients B }\end{array}$ & S.E. & $\begin{array}{c}\text { Standardized } \\
\text { coefficients } \\
\text { Beta }\end{array}$ & $\mathbf{t}$ & Sign. & Tolerance & VIF \\
\hline (Constant) & -0.100 & 0.035 & & -2.819 & 0.005 & & \\
\hline $\begin{array}{l}\text { Upper } \\
\text { secondary } \\
\text { education* }\end{array}$ & 0.200 & 0.015 & 0.094 & 13.489 & 0.000 & 0.745 & 1.342 \\
\hline $\begin{array}{l}\text { Tertiary } \\
\text { education }\end{array}$ & 0.503 & 0.021 & 0.214 & 23.594 & 0.000 & 0.439 & 2.280 \\
\hline Female & -0.052 & 0.013 & -0.026 & -4.142 & 0.000 & 0.918 & 1.089 \\
\hline $\begin{array}{l}25-35 \text { years } \\
\text { old }\end{array}$ & 0.139 & 0.016 & 0.059 & 8.623 & 0.000 & 0.767 & 1.304 \\
\hline $\begin{array}{l}36-50 \text { years } \\
\text { old }\end{array}$ & 0.048 & 0.014 & 0.023 & 3.457 & 0.001 & 0.795 & 1.258 \\
\hline $\begin{array}{l}\text { Middle- } \\
\text { Lower Class }\end{array}$ & -0.052 & 0.024 & -0.024 & -2.138 & 0.033 & 0.296 & 3.374 \\
\hline $\begin{array}{l}\text { Small } \\
\text { Business } \\
\text { Owners }\end{array}$ & -0.163 & 0.028 & -0.050 & -5.739 & 0.000 & 0.469 & 2.131 \\
\hline $\begin{array}{l}\text { Not Manual } \\
\text { Working } \\
\text { Class }\end{array}$ & -0.200 & 0.028 & -0.071 & -7.258 & 0.000 & 0.374 & 2.677 \\
\hline $\begin{array}{l}\text { Manual } \\
\text { Working } \\
\text { Class }\end{array}$ & -0.318 & 0.026 & -0.142 & 12.015 & 0.000 & 0.260 & 3.846 \\
\hline $\begin{array}{l}\text { Unemployed } \\
\text { or Inactive }\end{array}$ & -0.276 & 0.037 & -0.055 & -7.420 & 0.000 & 0.658 & 1.519 \\
\hline $\begin{array}{l}\text { Centre- } \\
\text { Western }\end{array}$ & 0.200 & 0.017 & 0.097 & 11.983 & 0.000 & 0.548 & 1.824 \\
\hline Anglo-Saxon & -0.253 & 0.022 & -0.083 & 11.608 & 0.000 & 0.714 & 1.400 \\
\hline Scandinavian & 0.362 & 0.030 & 0.079 & 12.099 & 0.000 & 0.847 & 1.181 \\
\hline Southern & 0.130 & 0.018 & 0.056 & 7.144 & 0.000 & 0.595 & 1.679 \\
\hline
\end{tabular}

Note: $11.0 \%$ of variance reproduced by model; values more negative are written in grey, values more positive in black.

*Advanced vocational included.

Besides, small business owners and working classes show once again their repulsion to multiculturalism, unlike upper-middle class. The residents in countries with corporative welfare regime (centre-western countries) display a propensity likewise favourable to this value, but the effect does not result particularly strong. The effect exercised by age cohort is even weaker, with a slightly positive propensity observed among the young people (25-35 years old).

Now moving to consider the type of interviewees' educational mobility, our research highlights that other things being equal, those who remain entrapped in a condition of cultural deprivation (Immobility at the Bottom) tend to express a strict identity adverse to diversities. Whereas, the most educated, especially those who have degree parents (Immobility at the Top) and the individuals who have proceeded educational mobility upward, are the most open towards migrants and 
cultural pluralism (Table 8).

Table 8. Multiple Linear Regression Model: The Effect of Educational Mobility on Multiculturalism, Other Conditions Being Equal

\begin{tabular}{|l|c|c|c|c|c|c|c|}
\hline & $\begin{array}{c}\text { Unstandardized } \\
\text { coefficients B }\end{array}$ & S.E. & $\begin{array}{c}\text { Standardized } \\
\text { coefficients } \\
\text { Beta }\end{array}$ & $\mathbf{t}$ & Sign. & Tolerance & VIF \\
\hline (Constant) & -0.180 & 0.038 & & -4.763 & 0.000 & & \\
\hline Female & -0.044 & 0.013 & -0.022 & -3.245 & 0.001 & 0.917 & 1.091 \\
\hline $\begin{array}{l}\text { 25-35 years } \\
\text { old }\end{array}$ & 0.123 & 0.018 & $\mathbf{0 . 0 5 3}$ & 7.010 & 0.000 & 0.748 & 1.336 \\
\hline $\begin{array}{l}\text { 36-50 years } \\
\text { old }\end{array}$ & 0.056 & 0.015 & 0.028 & 3.794 & 0.000 & 0.790 & 1.266 \\
\hline $\begin{array}{l}\text { Middle- } \\
\text { Lower Class }\end{array}$ & -0.055 & 0.025 & -0.025 & -2.152 & 0.031 & 0.310 & 3.222 \\
\hline $\begin{array}{l}\text { Small } \\
\text { Business } \\
\text { Owners }\end{array}$ & -0.155 & 0.030 & -0.048 & -5.174 & 0.000 & 0.486 & 2.057 \\
\hline $\begin{array}{l}\text { Not Manual } \\
\text { Working } \\
\text { Class }\end{array}$ & -0.198 & 0.029 & $-\mathbf{0 . 0 7 0}$ & -6.803 & 0.000 & 0.396 & 2.526 \\
\hline $\begin{array}{l}\text { Manual } \\
\text { Working } \\
\text { Class }\end{array}$ & -0.274 & 0.028 & -0.120 & -9.759 & 0.000 & 0.277 & 3.611 \\
\hline $\begin{array}{l}\text { Unemployed } \\
\text { or Inactive }\end{array}$ & -0.266 & 0.040 & -0.053 & -6.709 & 0.000 & 0.675 & 1.481 \\
\hline $\begin{array}{l}\text { Centre- } \\
\text { Western }\end{array}$ & 0.229 & 0.018 & $\mathbf{0 . 1 1 1}$ & 12.985 & 0.000 & 0.572 & 1.749 \\
\hline Anglo-Saxon & -0.190 & 0.025 & -0.056 & -7.502 & 0.000 & 0.769 & 1.301 \\
\hline Scandinavian & 0.362 & 0.031 & $\mathbf{0 . 0 8 2}$ & 11.585 & 0.000 & 0.848 & 1.179 \\
\hline Southern & 0.171 & 0.019 & $\mathbf{0 . 0 7 6}$ & 9.025 & 0.000 & 0.600 & 1.667 \\
\hline $\begin{array}{l}\text { Immobility } \\
\text { in the Middle }\end{array}$ & 0.236 & 0.017 & $\mathbf{0 . 1 0 9}$ & 14.033 & 0.000 & 0.696 & 1.437 \\
\hline $\begin{array}{l}\text { Downward } \\
\text { Mobility }\end{array}$ & 0.283 & 0.027 & 0.072 & 10.366 & 0.000 & 0.866 & 1.155 \\
\hline $\begin{array}{l}\text { Upward } \\
\text { Mobility }\end{array}$ & 0.520 & 0.024 & $\mathbf{0 . 2 0 5}$ & 21.721 & 0.000 & 0.472 & 2.117 \\
\hline $\begin{array}{l}\text { Immobility } \\
\text { at the Top }\end{array}$ & 0.601 & 0.033 & $\mathbf{0 . 1 4 7}$ & 18.455 & 0.000 & 0.666 & 1.502 \\
\hline Nore $0.7 \%$ \\
\hline
\end{tabular}

Note: $10.7 \%$ of variance reproduced by model; values more negative are written in grey, values more positive in black.

The two models just examined are equivalent and confirm our hypotheses. As regards the role of formal education, scholars that support the "Cultivation Theory" result more persuasive than those resorting to Rational Choice Theory: holding under control social class, the effect of education does not disappear by any means. At the same time, the second theory seems to be right when it states that less affluent classes are more closed to migrants for reasons that we can not merely attribute to the lack of high education. Nonetheless, the findings would seem to suggest that competition between natives and foreigners appear to be played mainly on the sociocultural side (symbolic competition) rather than that just economic one: as we wrote (see Table 6), individuals belonging to subaltern classes tend to have low cultural capital. Therefore they are less far from 
foreigners for social resources owned than how much they are far from the members of upper and middle classes.

The frame changes when we analyse the index of egalitarianism as the dependent variable (Table 9 and 10).

First of all, the new models are less explicative statistically. Only the five per cent of the variance of the dependent variable is reproduced by them; then, findings show education and educational mobility do not exercise any relevant influence, neither positive nor negative, on propensity to egalitarianism: the less propensity of graduates towards egalitarianism reduces to small differences, once we adopt a multivariate perspective.

Furthermore, the approval of egalitarianism does not seem to reflect any social cleavage, except reiterate that unemployed (and inactive) individuals and those one with high educated and belonging to family environments in which educational level is as much high (we are referring to the interviewees with "Immobility at the Top") is more adverse to the idea that contrasting social inequalities should be one of the most important duties of democratic institutions. Working class, instead, show a very slight tendency to connect democracy with social equality.

Table 9. Multiple Regression Model: The Effect of Formal Education Level on Egalitarianism, Other Conditions Being Equal

\begin{tabular}{|c|c|c|c|c|c|c|c|}
\hline & $\begin{array}{c}\text { Unstandardized } \\
\text { coefficients B }\end{array}$ & S.E. & $\begin{array}{c}\text { Standardized } \\
\text { coefficients } \\
\text { Beta }\end{array}$ & $\mathbf{t}$ & Sign. & Tolerance & VIF \\
\hline (Constant) & -0.043 & 0.035 & & -1.209 & 0.227 & & \\
\hline $\begin{array}{c}\text { Upper } \\
\text { secondary } \\
\text { education* }\end{array}$ & -0.005 & 0.015 & -0.003 & -0.373 & 0.709 & 0.743 & 1.346 \\
\hline $\begin{array}{c}\text { Tertiary } \\
\text { education }\end{array}$ & -0.090 & 0.021 & $\mathbf{- 0 . 0 3 8}$ & -4.208 & 0.000 & 0.438 & 2.285 \\
\hline $\begin{array}{c}\text { Female } \\
\text { 25-35 years old }\end{array}$ & -0.107 & 0.012 & $\mathbf{0 . 0 5 4}$ & 8.582 & 0.000 & 0.920 & 1.087 \\
\hline 36-50 years old & -0.040 & 0.016 & -0.044 & -6.431 & 0.000 & 0.770 & 1.298 \\
\hline $\begin{array}{c}\text { Middle-Lower } \\
\text { Class }\end{array}$ & 0.067 & 0.024 & -0.020 & -2.946 & 0.003 & 0.797 & 1.254 \\
\hline $\begin{array}{c}\text { Small Business } \\
\text { Owners }\end{array}$ & -0.009 & 0.028 & -0.003 & -0.317 & 0.751 & 0.464 & 2.157 \\
\hline $\begin{array}{c}\text { Not Manual } \\
\text { Working Class }\end{array}$ & 0.082 & 0.027 & 0.029 & 2.993 & 0.003 & 0.374 & 2.673 \\
\hline $\begin{array}{c}\text { Manual } \\
\text { Working Class }\end{array}$ & 0.091 & 0.026 & $\mathbf{0 . 0 4 1}$ & 3.446 & 0.001 & 0.257 & 3.893 \\
\hline $\begin{array}{c}\text { Unemployed or } \\
\text { Inactive }\end{array}$ & -0.100 & 0.037 & -0.020 & -2.669 & 0.008 & 0.661 & 1.514 \\
\hline $\begin{array}{c}\text { Centre- } \\
\text { Western }\end{array}$ & -0.249 & 0.016 & $-\mathbf{0 . 1 2 0}$ & -15.412 & 0.000 & 0.591 & 1.693 \\
\hline Anglo-Saxon & -0.402 & 0.022 & $\mathbf{- 0 . 1 2 9}$ & -18.568 & 0.000 & 0.752 & 1.330 \\
\hline Scandinavian & -0.243 & 0.030 & -0.052 & -8.050 & 0.000 & 0.872 & 1.147 \\
\hline \begin{tabular}{c} 
Southern \\
\hline Note: 5.2\% of
\end{tabular} & 0.212 & 0.018 & 0.090 & 11.989 & 0.000 & 0.635 & 1.574 \\
\hline
\end{tabular}

Note: $5.2 \%$ of variance reproduced by model; values more negative are written in grey, values more positive in black.

* Advanced vocational included 
Table 10. Multiple Regression Model: The Effect of Educational Mobility on Egalitarianism, Other Conditions Being Equal

\begin{tabular}{|c|c|c|c|c|c|c|c|}
\hline & $\begin{array}{l}\text { Unstandardized } \\
\text { coefficients B }\end{array}$ & S.E. & $\begin{array}{c}\text { Standardized } \\
\text { coefficients } \\
\text { Beta } \\
\end{array}$ & $\mathbf{t}$ & Sign. & Tolerance & VIF \\
\hline (Constant) & -0.075 & 0.037 & & -2.024 & 0.043 & & \\
\hline Gender & 0.108 & 0.013 & 0.055 & 8.160 & 0.000 & 0.917 & 1.090 \\
\hline $\begin{array}{l}25-35 \text { years } \\
\text { old }\end{array}$ & -0.104 & 0.017 & -0.045 & -6.029 & 0.000 & 0.751 & 1.332 \\
\hline $\begin{array}{c}36-50 \text { years } \\
\text { old }\end{array}$ & -0.036 & 0.015 & -0.018 & -2.494 & 0.013 & 0.792 & 1.263 \\
\hline $\begin{array}{c}\text { Middle- } \\
\text { Lower Class }\end{array}$ & 0.089 & 0.025 & 0.041 & 3.537 & 0.000 & 0.309 & 3.233 \\
\hline $\begin{array}{c}\text { Small } \\
\text { Business } \\
\text { Owners }\end{array}$ & 0.013 & 0.030 & 0.004 & 0.452 & 0.651 & 0.479 & 2.087 \\
\hline $\begin{array}{l}\text { Not Manual } \\
\text { Working } \\
\text { Class }\end{array}$ & 0.094 & 0.029 & 0.034 & 3.294 & 0.001 & 0.396 & 2.527 \\
\hline $\begin{array}{c}\text { Manual } \\
\text { Working } \\
\text { Class }\end{array}$ & 0.108 & 0.028 & 0.048 & 3.903 & 0.000 & 0.273 & 3.660 \\
\hline $\begin{array}{l}\text { Unemployed } \\
\text { or Inactive }\end{array}$ & -0.064 & 0.039 & -0.013 & -1.641 & 0.101 & 0.675 & 1.481 \\
\hline $\begin{array}{l}\text { Centre- } \\
\text { Western }\end{array}$ & -0.252 & 0.017 & -0.123 & $\begin{array}{c}- \\
14.870 \\
\end{array}$ & 0.000 & 0.613 & 1.631 \\
\hline Anglo-Saxon & -0.359 & 0.025 & -0.104 & $14 . \overline{380}$ & 0.000 & 0.801 & 1.248 \\
\hline Scandinavian & -0.253 & 0.031 & -0.056 & -8.137 & 0.000 & 0.872 & 1.147 \\
\hline Southern & 0.219 & 0.018 & 0.097 & 11.972 & 0.000 & 0.638 & 1.568 \\
\hline $\begin{array}{l}\text { Immobility in } \\
\text { the Middle }\end{array}$ & -0.003 & 0.016 & -0.001 & -0.166 & 0.869 & 0.691 & 1.446 \\
\hline $\begin{array}{l}\text { Downward } \\
\text { Mobility }\end{array}$ & 0.005 & 0.027 & 0.001 & 0.189 & 0.850 & 0.863 & 1.158 \\
\hline $\begin{array}{l}\text { Upward } \\
\text { Mobility }\end{array}$ & -0.038 & 0.024 & -0.015 & -1.626 & 0.104 & 0.471 & 2.121 \\
\hline $\begin{array}{l}\text { Immobility at } \\
\text { the Top }\end{array}$ & -0.184 & 0.032 & -0.046 & -5.752 & 0.000 & 0.667 & 1.500 \\
\hline
\end{tabular}

Note: $5.2 \%$ of variance reproduced by model; values more negative are written in grey, values more positive in black.

The role of institutional context appears quite peripheral: we can only state that egalitarianism is more diffused among Southern. In other words, interviewees living in countries characterised the weakest welfare regimes tend to request institutions contrast social inequalities, while the opposite tendency is detected among interviewees reside in Centre-Western Europe and Anglo-Saxon countries when we control the role of the other variables examined in the models.

Therefore, contrary to what we could have expected, even individuals living in a context characterized by a universalist welfare state (this is the case of Scandinavian countries) do not tend to think that democratic institutions have to remove social inequalities (perhaps because these institutions already act in this way and people take for granted a certain level of equality without asking a further 
redistributive action by State).

\section{Cognitive Mobility and Critical Thinking, the Roots of Democratic Universalism}

The theoretical framework we adopted allows us to carry on a more in-depth analysis, paying attention to the complex nature of socio-cultural processes and their embeddedness in real conditions of social actors.

The findings we reached so far confirm the influence of social conditions on way of thinking; for example, we noted the tendency of lower classes to identify themselves in closed communities, often artificial construction built by political institutions to avoid policies addressed to a real redistribution of economic resources (Appadurai 2017). This last phenomenon compensates the absence of class struggle.

However, our data lead us to think that the war among the most deprived persons, between natives and migrants, develop along a socio-cultural even before than economic line. It is true that most disadvantaged natives get to attribute their lousy condition, not to capitalistic exploitation but the competition of migrant workers, also if this competition is not always real. However, it more evident that, actually, several members of the working class often tend to discredit migrants because in this way they can avoid to perceive themselves at the bottom of the social scale.

This mechanism explains why the request of egalitarianism would not seem so relevant for working classes. At the same time, our data show that the repulsion to egalitarianism would not be attributable particularly to upper classes so easily, once you also consider the interviewees' educational level.

As we said, education should exercise an ambivalent function: it facilitates competitive dynamics and individual ambition, but at the same time it transmits values, beliefs and also cognitive competencies addressed to the recognition of the other and oriented to a universal worldview point promoting equality.

So far we saw that education affects positively on multiculturalism, whereas this influence is less clear and less strong on egalitarianism. Nevertheless, if we examine the attitude of being favourable to both values examined, we obtain interesting and clearer findings.

In order to reach this aim, we classified interviewees in four types. On the one side we have the "particularists", adverse to both values we examined, and on the other side, we have the "universalists", namely those who request/express the democratic universalism as well we defined it previously.

The figure 1 shows that universalists are more homogeneous than other interviewees (standard deviation on multiculturalism is 0.0551; standard deviation on egalitarianism is 0.270): they have a positive but variable score on multiculturalism and a level of egalitarianism greater than mean. On the contrary, particularists are more heterogeneous, especially for the degree of egalitarianism (standard deviation on multiculturalism is 0.624; standard deviation on egalitarianism is 1.027): some of them are not too far from the mean value, but others express the opinion that reflect a determined anti-egalitarianism.

A similar level of heterogeneity is observed among interviewees classified as 
"only multiculturalists" (standard deviation: 0.515 on the first factor; 0.807 on the second one), who show a positive score on the index that gives them the name and a negative score on the other index. Eventually, interviewees, we defined "only egalitarians" show a degree of heterogeneity that is at the halfway between universalists and the other two groups (standard deviation on multiculturalism is 0.661 ; standard deviation on egalitarianism is 0.266 ).

Figure. 1. The Interviewees' Position on the Two Indexes

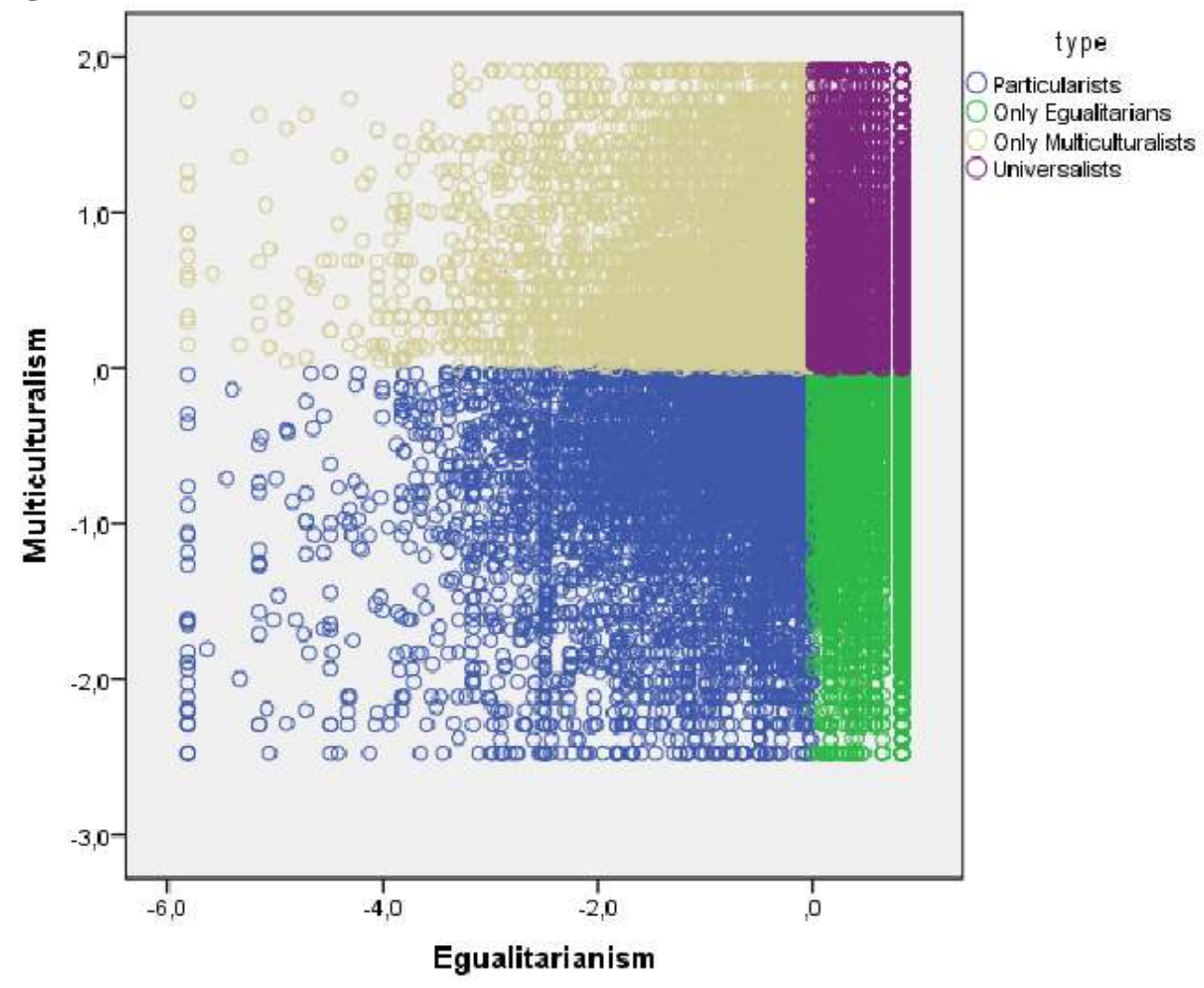

The resorting to the polynomial logistic regression allows to build two models reproducing respectively $15.1 \%$ and $15.4 \%$ of the dependent variable, that is the interviewees' likelihood of being other than "particularists".

These models are not only more explicative than previous ones, but they also clarify the role of education towards universalism.

Indeed, the first model (Table 11) shows how the possession of degree slightly reduces the likelihood of being only egalitarian rather than particularist, but it significantly increases the possibility of being only multiculturalist or even universalist rather than particularist.

To be more exact, if it is true that education promotes multiculturalism rather than universalism, however the likelihood of being universalist (rather than particularist) by an individual with a degree is $94 \%$ higher than the same probability measured among individuals without upper secondary diploma (and it is $61 \%$ higher than the likelihood observed among interviewees just with upper secondary diploma).

Table. 11. Multinomial Logistic Regression Model: Propensity to have an Attitude 
Different from Particularism on the Basis of Educational Level, Being Equal Other Conditions

\begin{tabular}{|c|c|c|c|c|c|c|c|c|c|}
\hline & \multicolumn{3}{|c|}{ Only Egualitarians } & \multicolumn{3}{|c|}{ Only Multiculturalists } & \multicolumn{3}{|c|}{ Universalists } \\
\hline & B & Sign. & $\operatorname{Exp}(B)$ & B & Sign. & $\operatorname{Exp}(B)$ & B & Sign. & $\operatorname{Exp}(B)$ \\
\hline Constant & 0,623 & 0,000 & & $\begin{array}{c}- \\
0,735 \\
\end{array}$ & 0,000 & & 0,008 & 0,943 & \\
\hline Tertiary & $\begin{array}{c}- \\
0,232 \\
\end{array}$ & 0,003 & 0,793 & 1,016 & 0,000 & 2,761 & 0,665 & 0,000 & 1,944 \\
\hline $\begin{array}{l}\text { Upper secondary } \\
\text { or advanced } \\
\text { vocational }\end{array}$ & 0,069 & 0,139 & 0,933 & 0,356 & 0,000 & 1,427 & 0,281 & 0,000 & 1,325 \\
\hline $\begin{array}{l}\text { Without upper } \\
\text { secondary } \\
\text { education } \\
\text { (reference } \\
\text { category) }\end{array}$ & & . & . & & . & $\cdot$ & & . & . \\
\hline Female & 0,142 & 0,001 & 1,152 & $\begin{array}{c}- \\
0,252 \\
\end{array}$ & 0,000 & 0,777 & 0,045 & 0,261 & 1,046 \\
\hline $25-35$ & $\begin{array}{c}- \\
0,233 \\
\end{array}$ & 0,000 & 0,792 & 0,421 & 0,000 & 1,523 & 0,043 & 0,399 & 1,044 \\
\hline $36-50$ & $\begin{array}{c}- \\
0,100 \\
\end{array}$ & 0,023 & 0,904 & 0,169 & 0,001 & 1,184 & 0,013 & 0,760 & 1,013 \\
\hline $\begin{array}{l}\text { 51-65 (reference } \\
\text { category) }\end{array}$ & & $\cdot$ & . & & . & . & & . & . \\
\hline $\begin{array}{l}\text { Middle-Upper } \\
\text { Class }\end{array}$ & 0,068 & 0,603 & 1,070 & 0,556 & 0,000 & 1,744 & 0,706 & 0,000 & 2,025 \\
\hline $\begin{array}{l}\text { Middle-Lower } \\
\text { Class }\end{array}$ & 0,086 & 0,409 & 1,090 & 0,293 & 0,016 & 1,340 & 0,573 & 0,000 & 1,774 \\
\hline $\begin{array}{l}\text { Small Business } \\
\text { Owners }\end{array}$ & $\begin{array}{c}- \\
0,149\end{array}$ & 0,185 & 0,862 & 0,004 & 0,976 & 1,004 & 0,126 & 0,270 & 1,134 \\
\hline $\begin{array}{l}\text { Non-manual } \\
\text { Working Class }\end{array}$ & 0,121 & 0,260 & 1,128 & $\begin{array}{c}- \\
0,066\end{array}$ & 0,603 & 0,936 & 0,392 & 0,000 & 1,480 \\
\hline $\begin{array}{l}\text { Manual Working } \\
\text { Class }\end{array}$ & 0,151 & 0,143 & 1,163 & $\begin{array}{c}- \\
0,294 \\
\end{array}$ & 0,018 & 0,745 & 0,167 & 0,117 & 1,182 \\
\hline $\begin{array}{l}\text { Unemployed or } \\
\text { Inactive } \\
\text { (reference } \\
\text { category) }\end{array}$ & & . & . & & . & . & & . & . \\
\hline Centre-Western & $\begin{array}{c}- \\
0,638 \\
\end{array}$ & 0,000 & 0,528 & $\mathbf{0 , 5 5 9}$ & 0,000 & 1,750 & $\begin{array}{c}- \\
0,218 \\
\end{array}$ & 0,000 & 0,804 \\
\hline Anglo-Saxon & $\begin{array}{c}- \\
0,742 \\
\end{array}$ & 0,000 & 0,476 & $\begin{array}{c}- \\
0,312 \\
\end{array}$ & 0,000 & 0,732 & $\begin{array}{c}- \\
0,967 \\
\end{array}$ & 0,000 & 0,380 \\
\hline Scandinavian & $\begin{array}{c}- \\
0,903\end{array}$ & 0,000 & 0,405 & 0,637 & 0,000 & 1,891 & $\begin{array}{c}- \\
0,071\end{array}$ & 0,447 & 0,932 \\
\hline Southern & 0,420 & 0,000 & 1,522 & 0,257 & 0,001 & 1,294 & 0,665 & 0,000 & 1,945 \\
\hline $\begin{array}{l}\text { Eastern } \\
\text { (reference } \\
\text { category) }\end{array}$ & & . & , & & , & the & & . & the \\
\hline
\end{tabular}

Note: $15.1 \%$ of variance is reproduced by the model; the values more negative are written in grey, values more positive in black. To understand accurately the meaning of the value attributed to a certain modality you have to compare this value with the other ones attributed to the modalities of the same variable. You have not to forget that the basis of comparison is the reference category for each variable.

Therefore, education exercises a crucial role, once you consider social class 
and the other variables here examined. The fact that Middle-Upper Class and Lower-Middle Class, followed by Non-Manual Working Class, are more universalist seem partly attributable to their relative advantaged condition, that is far from the state experienced by who exercises manual labour, like the members of the traditional working class and several small business owners. The last two groups are the least multiculturalists and the least universalists.

The findings of the first model suggest that, in contrast to what Cultivation Theories state, thought is embedded in social conditions (Marx and Engels 1845) but, on the contrary of what Rational Choice Theory scholars believe, education is a cognitive resource that partly makes individuals watch the world not only on the basis of their immediate and material interests. For example, tertiary education, that is connected to a long scholastic socialisation, shapes social identities towards to the openness to the other.

Moreover, the institutional context would seem to count, but it does not work following an additive mechanism. Interviewees from countries with a more universalist welfare state (Scandinavian Model) do not tend to be the most inclined to universalism. Instead, the likelihood of being universalists increases among Southern European interviewees, geographically in closest contact with migration flows and characterised by a weaker institutional system that leads them to ask more equality, given the low social protection assured in their country (Table 11).

The second model confirms the results of the first one, but also shows when the role of education becomes stronger and more relevant. About this, the model illustrates in which conditions education affects someone's attitude towards to world. First of all, our data show that when you belong to a family without upper secondary education, and you are not in the condition of improving your sociocultural condition (this is the case of the individuals with "immobility at the bottom"), then you tend to be particularist or at most only egalitarian. On the opposite the attitude of being universalist increases when you confirm the good cultural capital of parents (this is the case of persons with "immobility at the top").

Not only, but the openness to a universalist worldview point is also more likely for individuals who reach a level of education higher than their parents' one: this is the case of Individuals with an "upward educational mobility" (Table 12).

If we examine all the models together (therefore also those illustrated in the previous paragraph), we can state that tertiary education is crucial for individual coming from lower classes. 
Table 12. Multinomial Logistic Regression Model: Propensity to have an Attitude Different from Particularism on the Basis of Educational Level, Being Equal other Conditions

\begin{tabular}{|c|c|c|c|c|c|c|c|c|c|}
\hline & \multicolumn{3}{|c|}{ Only Egualitarians } & \multicolumn{3}{|c|}{$\begin{array}{c}\text { Only } \\
\text { Multiculturalists }\end{array}$} & \multicolumn{3}{|c|}{ Universalists } \\
\hline & B & Sign. & $\operatorname{Exp}(B)$ & $\mathbf{B}$ & Sign. & $\operatorname{Exp}(B)$ & $\mathbf{B}$ & Sign. & $\operatorname{Exp}(B)$ \\
\hline Constant & 0,717 & 0,000 & & $\begin{array}{c}- \\
0,742 \\
\end{array}$ & 0,000 & & 0,117 & 0,353 & \\
\hline $\begin{array}{l}\text { Immobility in the } \\
\text { Middle }\end{array}$ & $\begin{array}{c}- \\
0,048 \\
\end{array}$ & 0,361 & 0,953 & 0,423 & 0,000 & 1,527 & 0,334 & 0,000 & 1,397 \\
\hline Downward Mobility & $0, \overline{166}$ & 0,065 & 0,847 & 0,397 & 0,000 & 1,487 & 0,412 & 0,000 & 1,509 \\
\hline Upward Mobility & $\begin{array}{c}- \\
0,159 \\
\end{array}$ & 0,074 & 0,853 & 0,987 & 0,000 & 2,682 & $\mathbf{0 , 7 8 3}$ & 0,000 & 2,188 \\
\hline Immobility at the Top & $\begin{array}{c}- \\
0,318\end{array}$ & 0,016 & 0,728 & 1,299 & 0,000 & 3,667 & 0,641 & 0,000 & 1,898 \\
\hline $\begin{array}{l}\text { Immobility at the } \\
\begin{array}{l}\text { Bottom } \\
\text { category) }\end{array} \\
\text { (reference }\end{array}$ & & . & , & & . & . & & . & . \\
\hline Female & $\mathbf{0 , 1 3 5}$ & 0,003 & 1,144 & $\overline{0}, \overline{232}$ & 0,000 & 0,793 & 0,083 & 0,054 & 1,087 \\
\hline $25-35$ & $\begin{array}{c}- \\
0,234 \\
\end{array}$ & 0,000 & 0,791 & 0,364 & 0,000 & 1,439 & 0,021 & 0,705 & 1,022 \\
\hline $36-50$ & 0,089 & 0,067 & 0,915 & 0,162 & 0,002 & 1,176 & 0,039 & 0,406 & 1,040 \\
\hline $\begin{array}{ll}51-65 & \text { (reference } \\
\text { category) } & \\
\end{array}$ & & . & . & & . & . & & . & . \\
\hline Middle-Upper Class & $\begin{array}{c}- \\
0,045\end{array}$ & 0,748 & 0,956 & $\mathbf{0 , 5 0 0}$ & 0,001 & 1,649 & 0,649 & 0,000 & 1,914 \\
\hline Middle-Lower Class & 0,011 & 0,925 & 1,011 & 0,200 & 0,129 & 1,222 & $\mathbf{0 , 5 5 3}$ & 0,000 & 1,739 \\
\hline $\begin{array}{ll}\text { Small } & \text { Business } \\
\text { Owners } & \\
\end{array}$ & $\begin{array}{c}- \\
0,200\end{array}$ & 0,102 & 0,819 & $\begin{array}{c}- \\
0,048 \\
\end{array}$ & 0,737 & 0,953 & 0,140 & 0,265 & 1,150 \\
\hline $\begin{array}{l}\text { Non-manual Working } \\
\text { Class }\end{array}$ & $\begin{array}{c}- \\
0,009 \\
\end{array}$ & 0,935 & 0,991 & $\begin{array}{c}- \\
0,094 \\
\end{array}$ & 0,495 & 0,910 & $\mathbf{0 , 3 4 7}$ & 0,004 & 1,415 \\
\hline $\begin{array}{ll}\text { Manual Working } \\
\text { Class }\end{array}$ & $\begin{array}{c}- \\
0,006\end{array}$ & 0,956 & 0,994 & $\begin{array}{c}- \\
0,320\end{array}$ & 0,017 & 0,726 & 0,201 & 0,086 & 1,223 \\
\hline $\begin{array}{l}\text { Unemployed or } \\
\text { Inactive (reference } \\
\text { category) }\end{array}$ & & & & & & & & . & \\
\hline Centre-Western & $\begin{array}{c}- \\
0,671 \\
\end{array}$ & 0,000 & 0,511 & 0,598 & 0,000 & 1,819 & $0, \overline{202}$ & 0,000 & 0,817 \\
\hline Anglo-Saxon & $\begin{array}{c}- \\
0,636 \\
\end{array}$ & 0,000 & 0,529 & $0, \overline{200}$ & 0,022 & 0,819 & $\begin{array}{c}- \\
0,820 \\
\end{array}$ & 0,000 & 0,440 \\
\hline Scandinavian & $\begin{array}{c}- \\
0,909\end{array}$ & 0,000 & 0,403 & 0,621 & 0,000 & 1,861 & $\begin{array}{c}- \\
0,094\end{array}$ & 0,336 & 0,910 \\
\hline Southern & 0,431 & 0,000 & 1,538 & 0,324 & 0,000 & 1,382 & 0,755 & 0,000 & 2,128 \\
\hline $\begin{array}{ll}\text { Eastern } & \text { (reference } \\
\text { category) } & \end{array}$ & & & & & & & & 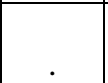 & \\
\hline
\end{tabular}

Note: $15.4 \%$ of variance is reproduced by the model; the values more negative are written in grey, values more positive in black. To understand accurately the meaning of the value attributed to a certain modality you have to compare this value with the other ones attributed to the modalities of the same variable. You have not to forget that the basis of comparison is the reference category for each variable. 
Indeed, interviewees with an upward educational mobility show a likelihood of being universalists that are $200 \%$ higher than the same likelihood revealed among interviewees who, like their parents, do not have upper secondary diploma, and so they live the reproduction of socio-cultural gap paid by their origins family (we are referring to individuals with "immobility at the bottom").

It is important to highlight that individuals who live educational mobility tend to be universalist to a greater extent also than those achieve tertiary education confirming their educational background. The likelihood of being universalists rather than particularists by interviewees with upward educational mobility is $30 \%$ higher than the same likelihood of interviewees that reproduce the high level of education of their family (in this last case we talk about individuals with an educational "immobility at the top").

\section{Summary and Discussion}

This paper set out to understand how much education promotes democratic universalism, namely the value inspiring the modern democracy according to which institutions have to guarantee social equality (Honneth 2016). In current Europe, this value requests to be reworked, considering multiculturalism: equality is promoted just if it entails the recognition of the freedom to express cultural diversity. Otherwise, universalism downgrades to cultural imperialism, producing exclusion rather than social inclusion.

The analysis of data gathered by the sixth edition of ESS highlighted that egalitarianism and multiculturalism are not correlated, with the first value in partial crisis, like Crouch $(2004,2014)$ spotted, whereas the second value splits European public opinion.

Given this situation, some scholars remark the socializing role of educational system (Hainmueller and Hiscox 2007, Sciolla 2013, Assirelli 2014); the achieving of a high level of education, in particular the degree comes from a longtime scholastic socialisation thanks to which democratic values and attitudes are learned: tolerance for diversities, cultural pluralism and civic sense.

Nonetheless, Rational Choice scholars attribute values, norms, opinions and attitudes to the material interests connected to social positions of individuals, not to scholastic socialisation: high education would not guarantee the openness of mind. According to these scholars, if researchers considered interviewees' social class, the effect exercised by education on removal of prejudices and recognition of the other would disappear or would be very weak (Malchow-Møller et al. 2006, Wodtke 2012).

Other researches, like that one about professionals carried on by Brint (1996), came to identify a positive association between education and openness to cultural diversity, but not between the first one and egalitarianism.

According to us, we may analyse better the question considering the ambivalence of educational system: schools reproduce social inequalities, justifying them on behalf of universalism (Bourdieu 1984), but just this promise feeds up the belief in social mobility and emancipation (Collins 1979, Parziale 
2016).

Therefore, we elaborated two hypotheses that pay attention to the "cognitive and symbolic function of education", without ignoring the inverse function of reproducing of social inequalities.

In other words, scholastic socialisation has an ambivalent nature: on the one hand it justifies the reproduction of social inequalities to which schools also contribute; on the other hand, it provides individuals achieving high level of education with values and cognitive competencies that foster the recognition of the other (Colombo 2014), feeding up a universalistic worldview point.

Our regression models highlight precisely this contradiction that we have interpreted by resorting to a theoretical framework based on the social embeddedness of thought (Marx and Engels 1845), combining it with the idea that the texts produced by socialization shape the identity of individuals thanks to the "appropriation" of the former by the latter ones (Ricoeur 1986).

The main finding of our research is that the educational system encourages universalism - today to be understood as a combination of egalitarianism and multiculturalism (Kymlicka 1995) - when it enhances values and beliefs of individual belonging to most educated families, also if these last ones correspond to most advantaged classes, or when it promotes the educational mobility of individuals coming from lower classes.

In particular, individuals with upward educational mobility migrate by a deprived socio-cultural condition to another better one. This social trajectory seems to make scholastic socialisation of universalism more effectiveness; scholastic socialisation is not a mere transmission of values, norms and beliefs, but it consists in the acquiring of a specific cultural code: working-class students have to pass from a "restricted code" to an "elaborated code" in order to achieve an excellent scholastic performance (Bernstein 1975, 2006). The second type of code allows developing theoretical thinking that in turn pushes individuals to (try to) go beyond particularism connected to gender, ethnic, religious or class belonging.

In other words, we can identify a mechanism according to which persons follow a trajectory that denies the common mechanism of reproducing of educational inequalities by schools (Scuola di Barbiana 1967, Willis 1977, Bourdieu 1979, Bowles and Gintis 2003, Apple 2012). For this reason, we may define individuals with educational mobility as "Heretics" (Parziale 2016): in several cases, their identity is the outcome of a deeper socialisation derived by the acquiring of a cultural code different from what they learned in primary socialisation.

Indeed, those who move from the first to the second code experience a profound change that entails the counteracting of prejudices. In this case, the long educational path seems to be connected to the authentic recognition of differences (Adorno et al. 1950, Honneth 1992, Taylor 1994): this trajectory encourages a positive attitude to egalitarianism, and thus to the universalism.

In this sense, you may say that in general people with high education tend to develop "post-conventional thinking" (Kohlberg 1971, Habermas 1976). This kind of thinking is focused on the autonomy of the subject against the constraints of the political and economic system. In this case, the educational system makes not only 
one learns "the generalised other" (Mead 1934), so that he/she becomes a member of society, but also this one develops a critical sense that goes beyond the social constraints (Habermas 1984).

Therefore, we come to conclude that schools can represent one of the leading agencies promoting a forma mentis favourable to democratic universalism in the current pluralistic societies, as long as they support social inclusion and education mobility. This last phenomenon does not help only to guarantee meritocracy or to nourish trust in democratic institutions (possibly through misleading), but above all, it constitutes a virtuous path during which teachers succeed in convincing students to make that "extra effort" allowing them the modification of the starting cultural code.

This effort does not lead to the reproduction of familial, cultural competencies (Bourdieu 1984), instead it causes the questioning of common feeling, certainties of own social world, opening the way for the condition of "disoriented" like a foreigner in a new Country (Schütz 1962): those who live educational mobility are led to develop better the capability to distance themselves from cultural objectivations.

This outcome produces that critical sense Gouldner (1979) attributed to that group he called the "new class" ("the service class") in the past, and today we can attribute to the broader expansion of cognitive work among middle classes ${ }^{5}$.

Perhaps, our paper allows to glimpse an effect of this process in the age of globalisation; we mean the birth of a new social cleavage between individuals with tertiary education and individuals lower educated. But, our research suggests not to refer this cleavage to an abstract learning process, separated from social stratification system and real educational practices. We may state that scholastic socialisation is comparable to "texts" that are interpreted differently according to the real social and educational trajectories crossed by its "readers".

\section{References}

Adorno TW, Frenkel-Brunswick E, Levinson DJ, Sanford RN (1950) The Authoritarian Personality. New York: Harper-Row.

Aidukaite J (2011) Welfare reforms and socio-economic trends in the 10 new EU member states of Central and Eastern Europe. In Communist and post-communist studies 44(3): 211-219.

Appadurai A (2017) The Democracy Fatigue. In H Geiselberger (ed), The Great Regression. Cambridge (UK): Polity Press.

Apple MW (2004) Ideology and curriculum. London and New York: Routledge.

Apple MW (2012) Can education change society? London and New York: Routledge.

Apple MW (2013) Education and power. London and New York: Routledge.

Assirelli G (2014) Studiare di più rende cittadini migliori? Analisi della relazione tra istruzione e civicnessin Italia. In Scuola democratica 1: 29-52.

Bernstein B (1975) Towards a Theory of Educational Transmissions, vol. 3. London:

\footnotetext{
${ }^{5}$ In the same way as the classic sociologists (Weber 1920, Simmel 1908, Elias 1936, Habermas 1981), also Gouldner connects scholastic socialisation to the broader process of rationalization and intellectualisation of the world.
} 
Routledge \& Kegan Paul.

Bernstein B (2006) Vertical and horizontal discourse: An essay. In Education and Society, 53-73. Routledge.

Berger P, Luckmann T (1966) The social construction of reality: A treatise in the sociology of knowledge. New York: Garden City.

Boudon R (1973) L'inegalité des chances. Paris: Armand Colin.

Bourdieu P (1979) La Distinction. Critique sociale dujugement. Paris: Editions de Minuit.

Bourdieu P (1984) Homo academicus. Paris: Editions de Minuit.

Bowles S, Gintis H (2003) Schooling in capitalist America twenty-five years later. In Sociological Forum 18(2): 343-348.

Brint S (1996) In an age of experts: The changing role of professionals in politics and public life. Princeton: Princeton University Press.

Brint S (1998) Schools and Societies. Stanford: Stanford University Press.

Bukodi E, Goldthorpe JH (2012) Causes, Classes and Cases. In Longitudinal and Life Course Studies 3: 292-296.

Collins R (1979) The Credential Society: An Historical Sociology of Education and Stratification. New York: Academic Press.

Colombo E (2014) Istruzione e atteggiamento nei confronti della differenza culturale. Una rassegna delle principali interpretazioni sociologiche. In Scuola democratica 1: 9-28.

Crouch C (2004) Post-democracy. Cambridge: Polity Press.

Crouch C (2014) Il potere dei giganti: Perché la crisi non ha sconfitto il neoliberismo. Bari: Laterza.

Cuche D (2006) La nozione di cultura nelle scienze sociali, Il Mulino, Bologna.

Dewey J (1916) Education and democracy. Macmillan, New York.

Di Franco G, Marradi A (2003) Analisi fattoriale e analisi in componenti principali. Acireale: Bonanno.

Elias N. (1936) ÜberdenProzessderZivilisation. Basel: HauszumFalken. [it.tr. La civiltà delle buone maniere. Le trasformazioni dei costumi nel mondo aristocratico occidentale. Bologna: il Mulino, 2009].

Erikson R, Goldthorpe JH (1992) Individual or family? Results from two approaches to class assignment. In Acta Sociologica 35(2): 95-105.

Erikson R, Goldthorpe JH, Portocarero L (1979) Intergenerational class mobility in three Western European societies: England, France and Sweden. In The British Journal of Sociology 30(4): 415-441.

Esping-Andersen G (2013), The three worlds of welfare capitalism. New York: John Wiley \& Sons.

Ferrara A (2011) Democrazia e apertura. Milano: Mondadori.

Gallino L (2013) La lotta di classe dopo la lotta di classe. Bari: Laterza.

Geiselberger H (ed) (2017) The Great Regression. Cambridge: Polity Press.

Gerbner G., Gross L., Morgan M., Signorielli N., Living with television: The dynamics of the cultivation process, in J. Bryant, D. Zillmann (Eds.), Perspectives on media effects, Lawrence Erlbaum, Hillsdale, 1986, pp. 17-40.

Giroux HA (2005) Schooling and the struggle for public life. Democracy's promise and education's Challenge. Boulder: Paradigm Publishers.

Giroux HA, McLaren P (eds) (2014) Between borders: Pedagogy and the politics of cultural studies. London and New York: Routledge.

Goldthorpe JH (2000) Social class and the differentiation of employment contracts. In On Sociology: Numbers, Narratives and the Integration of Research and Theory. Oxford: Oxford University Press.

Goldthorpe JH (2016) Social class mobility in modern Britain: changing structure, 
constant process. Journal of the British Academy 4: 89-111.

Gouldner AW (1979) The future of intellectuals and the rise of the new class. New York: Macmillan.

Habermas J (1976) Zur Rekonstruktion des historischen Materialismus. Frankfurt a. M.: Surkhamp.

Habermas J (1981) Theorie des kommunikativenHandelns. Frankfurt a. M.: Surkhamp.

Harvey D (2007) A brief history of neoliberalism. New York: Oxford University Press.

Honneth A (1992) Integrity and disrespect: Principles of a conception of morality based on the theory of recognition. In Political Theory 20(2): 187-201.

Honneth A (2016) L'idea di socialismo: Un sogno necessario. Milano: Feltrinelli Editore.

Hainmueller J, Hiscox MJ (2007) Educated preferences: Explaining attitudes toward immigration in Europe. In International Organization 61(2): 399-442.

Hall S (1980) Cultural studies: Two paradigms. In Media, Culture \& Society 2(1): 57-72.

Izzo A (1966) Sociologia della conoscenza. Roma: Armando Editore.

Jackson M (2013) Determined to succeed?: performance versus choice in educational attainment. Stanford: Stanford University Press.

Kohlberg L (1971) Stages of moral development. Moral education 1: 23-92.

Kymlicka W (1995) Multicultural citizenship: A liberal theory of minority rights. Oxford: Clarendon Press.

Lipset SM (1960) Political man: The social bases of politics. New York: Garden City.

Malchow-Møller N, Munch J, Schroll S, Skaksen J (2006) Attitudes towards immigration: does economic self-interest matter? IZA Discussion Paper, n. 2283.

Mannheim K (1936) Ideology and utopia. New York: Harcourt.

Marramao G (2015) Commento. Democrazia deliberativa e universalismo della differenza. Parole chiave 23(1): 57-62.

Marx K, Engels F (1932) De Duitse ideologie, manuscript of 1845. Berlin: Dietz Verlag.

Mayo P (2015) Hegemony and education under neoliberalism: Insights from Gramsci. London: Routledge.

Mead GH (1934) Mind, self and society. Chicago: University of Chicago Press.

Nie NH, Junn J, Stehlik-Barry K (1996) Education and democratic citizenship in America. Chicago: University of Chicago Press.

Nussbaum MC (1997) Cultivating humanity. Cambridge, MA: Harvard University Press.

Oesch D (2003) Labour market trends and the Goldthorpe class schema: A conceptual reassessment. In Revue Suisse de Sociologie 29(2): 241-262.

Parziale F (2016) Eretici e respinti. Classi sociali e istruzione superiore in Italia. Milano: Franco Angeli.

Parziale F, Scotti I (2008) Valutazione delle occupazioni e gruppi socio-occupazionali. In Sociologia del Lavoro 112: 63-79.

Piketty T (2014) Capital in the Twenty First Century. Cambridge, MA: University Press.

Ricoeur P (1986) Lectures on ideology and utopia. New York: Columbia University Press. Rosenberg M (1968) The Logic of Survey Analysis. New York: Basic Books.

Schütz A (1962) Collected Papers I. Dordrecht: Springer.

Sciolla L (2013) Il ruolo dell'istruzione formale nella formazione dei valori e dei comportamenti di cittadinanza attiva. In Scuola Democratica 3(2013): 839-849.

Scuola di Barbiana (1967) Lettera a una professoressa. Firenze: Libreria Editrice Fiorentina.

Simmel G (1908) Soziologie. Untersuchungenüber die Formen der Vergesellschaftung. Leipzig: Duncker \& Humblot.

Taylor C (1994) Multiculturalism and the Politics of Recognition: An Essay. Princeton: Princeton University Press.

Thompson JB (1995) The media and modernity: A social theory of the media. Stanford: 
Stanford University Press.

Weber M (1920) Gesammelte Aufsätze zur Religions soziologie. Tübingen: J.C.B. Mohr.

Williams R (1973) Base and superstructure in Marxist cultural theory. In New left review 82: 3-16.

Willis P (1977) Learning to Labour. New York: Columbia University Press.

Wodtke GT (2012) The impact of education on intergroup attitudes: A multiracial analysis. In Social Psychology Quarterly 75(1): 80-106.

Wright O (1985) Classes. London: Verso.

Žižek S (2017) The Populist Temptation. In H Geiselberger (ed) The Great Regression. Cambridge: Polity Press. 